\title{
The Necessity for Education and Training within the Survivalist Retail Entrepreneurship Sector
}

\author{
Chux Gervase Iwu*, Saphetha Gwija, Robertson Tengeh, Chris Cupido, Roger B Mason \\ Cape Peninsula University of Technology, South Africa \\ *IwuC@cput.ac.za
}

\begin{abstract}
This paper investigates the necessity for education and training within the survivalist retail entrepreneurship sector in Khayelitsha, in the Western Cape Province of South Africa. A structured questionnaire, informal interviews and observations were employed to collect data. To analyse the collected data, Statistical Package for the Social Sciences (SPSS version 23) was employed. A total of 150 questionnaires were distributed, but only 128 usable completed copies were returned. The key findings were twofold: (1) an admission by the majority of the subjects that their businesses are not doing particularly well owing to their lack of basic business skills; and (2) the subjects' admission that competitive practices of the immigrant retail entrepreneurs in the township can be counteracted if they had adequate business skills. These findings imply that should survivalist retail entrepreneurs in Khayelitsha be expected to add greater value to the economy by creating employment opportunities, it is essential that they are provided with skills training on a regular basis by government agencies and other stakeholders such as the Wholesale and Retail Sector Education and Training Authority (W\&RSETA). This paper has its origin in the considered intention of the Wholesale and Retail Leadership Chair of $\mathrm{CPUT}^{1}$ to assist in developing the retail sector of the community of Khayelitsha.
\end{abstract}

Keywords: Informal survivalist retail entrepreneurs, education, skills training, informal sector economy, networking

\section{Introduction}

Since 1994, South Africa has 'enjoyed' democracy. However, there have been displays of unhappiness through protest actions mostly as a result of what can be described as unsatisfactory social and economic issues insufficient public utility and growing levels of unemployment - that urgently demand government attention. More than anything else, access to proper education (either formal or non-formal) is crucial, not just for an individual but the country as well (Arko-Achemfuor, 2014:607). Worryingly, the quality of education in South Africa is not satisfactory (Herrington, Kew \& Kew, 2009; Turton \& Herrington, 2012), probably as a result of the segregated educational system of the apartheid era (Bhorat, 2001), which deliberately subjected Blacks to a second-class education (Levinsohn, 2008). In addition Levisohn continues, labour laws were promulgated to impede the advancement of Black people, while business policies prohibited them from profitable participation in mainstream economic practices. And no doubt this situation 'created an unequal distribution of wealth and a high rate of unemployment and poverty across the country, leaving those who struggled throughout the apartheid era to excessively bear the price of unemployment and live below the poverty line' (Levinsohn, 2008). So those who are unable to access employment, perhaps as a result of the quality of education they posses, then resort to self-employment in the form of selling petty goods in the marketplace so as to provide basic necessities such as food and clothing. Nieman and Nieuwenhuizen (2009:34) regard reasons behind such behaviours as push factors, i.e. such individuals started businesses on the basis of necessity-, as opposed to opportunity, based reasons. This epitomises how informal survivalist entrepreneurship may emerge in society.

Informal micro and survivalist entrepreneurs seek to improve their lot and those of their families as well. For instance, the basic needs (such as food, water and electricity, clothes, school fees and transportation fare for their children, and so on) largely depend on the profits that the business generates, especially if there is no other source of income in the family. This means that the livelihood of households owning a survivalist

\footnotetext{
${ }^{1}$ Cape Peninsula University of Technology, South Africa
} 
enterprise depends on the success of that business. One can imagine the pressure that is on such a business to be profitable. The truth of the matter is that micro and survivalist entrepreneurs do not operate in a vacuum, and therefore are affected by most of the business environmental factors that their counterparts in the formal economy encounter (Co, Groenewald, Mitchell, Nayager, van Zyl, Visser, Train \& Emanual, 2006:13).

Of interest is that Hutchinson and de Beer (2013:237) maintain that informal micro and survivalist businesses are expressions of the discontent with the unfriendly socio-economic state of a country. Co et al. (2006:121) note that although the informal survivalist and micro-enterprise sector is large in South Africa, yet it continues to wrestle poverty with very little success. It is against this background that this study poses this important question: Can education and training be the long awaited remedy for a struggling informal survivalist retail entrepreneur in a less advantaged township such as Khayelitsha? The objective of this important research is to understand if there is a necessity for education and training for survivalist retail entrepreneurs in a less-advantaged township such as Khayelitsha.

Problem Statement: Despite the establishment of the National Small Business Act of 1996 and other government pioneered interventions that are aimed at facilitating the business environment in South Africa, the informal survivalist retail sector has remained largely under-developed. On one hand they are excluded from government's small business support services, while on the other, the pressures of family/households and stringent competitive practices of formal businesses can be stifling. The dynamics posed by globalisation are also problematic in the informal sector economy, as the sector is dominated by individuals with limited education. One can only imagine how far these determined survivalist entrepreneurs could progress should they access the support systems that they need the most. Such support systems could be in the form of capacity building or knowledge of how to successfully grow a business. Therefore, improvement of knowledge and creative thinking, in a competitive setting such as Khayelitsha, should be seen as a worthwhile investment. The present gaps do not only hold back these enterprises from transiting to the formal sector economy, but influence the entrepreneurs' standards of living as well.

\section{Literature Review}

Informal survivalist entrepreneurship in South Africa: In the South African context, when one speaks about small businesses one refers to firms that are independently owned and managed, and with 50 or fewer employees (Co et al., 2006:11), whereas in some countries such as Europe and USA the construct 'small business' implies firms that have employees ranging from 100 to 500 (Nieman, 2006). Again, in the South African context, small businesses are classified into micro, very small and small enterprises (South Africa, (2003: 8). Among these classifications of small businesses, micro-enterprises are dominant particularly in the informal sector economy, and are family owned and operate mostly in developing communities (Mago \& Toro, 2013: 21). Rolfe et al. (2010:5) describe the informal sector economy as the business environment in which informal businesses that are non-taxed and unregulated engage in economic activities. Nieman (2006:8) cites DTI (2003:28) which notes that most entrants into the business world start as microentrepreneurs for survival, with zero up to ten employees. Hence the term 'survivalist' is used to refer to informal businesses (including micro, and very small enterprises). This paper adopts the concept of 'survivalist' when referring to either micro or very small enterprise. Also, for the purpose of the study, the term 'survivalist' was adopted to refer to 'informal retail survivalist entrepreneurs' which forms the unit of analysis.

Even though survivalists can be found in the formal economy, what sets them apart from the formal businesses is that as informal enterprises they carry unique features that include the following: they operate as small-scale, very small businesses; mostly only the owner, with some family members and at most a couple of paid employees; inadequate formality in terms of business licensing, VAT registration, formal business premises, and accounting procedures; limited capital; and they lack technical or business skills among others (Nieman, 2006:8). Encouragingly, Mago and Toro (2013) affirm that these entrepreneurs provide for the livelihoods of thousands and thousands of people in South Africa. This could be the reason why Hutchinson and de Beer (2013:237) are of the view that informal survivalist entrepreneurship is the backbone of socioeconomic development in any economy. Choto, Tengeh and Iwu (2014:93) concur that survivalist enterprises 
have a significant impact in the country's economic growth. Charman, Petersen and Piper (2012:51) however, caution that even though informal sector economy presents potential opportunity for success, many, especially new entrants do not succeed. Naidoo and Urban (2010) locates lack of managerial skills among impediments of survivalist entrepreneurship, which extremely contributes to business collapse.

Necessity for improved skills for the survivalist retail entrepreneur: Herrington, Kew and Kew (2009:12) have noted that inadequate skills and education are the key impediments to the development of entrepreneurship in South Africa. Daniel and Sifuna (2007:689), Modisaotsile (2012), as well as Gyan, Mabefam and Baffaoe (2014:409) assert that proper education is critical to human development and maintenance of a socially responsive economic and political system. Gordhan (2012:21) also points out that the unpredictable and competitive global environment has forced many governments across the world to prioritise investment in their education. The types of education offered in many institutions (of either lower or higher learning) focus largely on the theoretical side and fail to introduce and expose students to practical entrepreneurship experience (Fal, Daniels, Williams \& Bantobetse, 2011:9; Arko-Achemfuor, 2014). This limits learners from practically applying what they have learned in class. In general, education is aligned to processes that are involved in acquiring knowledge, attitudes and values from public or private schooling environments. In the current study, we argue that formal education may not be suitable for survivalist retail entrepreneurs as they are unlikely to adapt to the rigour of teaching and learning practices of formal educational systems.

Contrary to formal education, informal education in the form of vocational/skills training, would be a viable route for improving the informal sector economy. This type of education can be associated with what ArkoAchemfuor (2014) refers to as hands-on practical training including, computer literacy, delivered in the form of short courses. With access to such courses, the survivalist entrepreneur can be exposed to new and worthwhile business ideas, as well as opportunities to access other networks. Albert Bandura's theory of social learning explains that people can learn by associating and/or observing the behaviour of others and the results of such behaviours. Through observation one is able to acquire large, integrated units of behaviour without having to build up the behavioural patterns regularly by tedious trial and error (Bandura, 1971:2). Burke (2006:96) suggests another recipe for business success, which could outweigh any portfolio of academic degrees and certification. Burke calls this networking with helpful contacts, who can give advice, information and resources that can facilitate the entrepreneur's business venture. Regarding the informal sector, networking skills are very important for survivalist retail entrepreneurs. Evidence of the use of the right networks can be indicated by the success of foreign nationals who operate spaza ${ }^{2}$ shops in the South African townships (Liedeman et al., 2013:4). Nieman and Nieuwenhuizen (2009:192) describe networking as the art of making and using the right contacts, which may include communication and exchange of information between parties of interest (e.g. friends, family members, customers, suppliers, bankers, professional associates, support structures, internet, business advisors, and so on).

\section{Methodology}

The research design for this study was exploratory in nature. To reinforce and balance the reviewed literature a structured questionnaire, unstructured interviews and observations were used to gather the necessary information. The combination of these methods is capable of fulfilling the intended purpose of the study. This is because they complement one other: where one is not strong enough to dig deeper to the crux of the phenomenon, the other compensates.

Population and sample size: In the context of research, population does not only refer to individuals, but also includes elements such as groups, organisations, human products, and events (Fox \& Bayat, 2007:51). Fox and Bayat describe population as a full set of any of these elements from which a sample can be drawn for interrogation. In this study the population comprised informal (unregistered and non-taxed) retail entrepreneurs from the selected township (known as Khayelitsha) in the Western Cape province of South Africa. The informal retail industry has gained some limelight recently owing to fierce competition between

${ }^{2} \mathrm{An}$ isiZulu concept, which was used to define informal businesses that were secretly operated from home by Black South Africans selling petty goods/groceries to make a living (Bear et al., 2005) . 
local (indigenes) and foreign (immigrant) informal retail entrepreneurs who own spaza shops in the townships. The informal retail industry in this township is large and varied, not only constituting spaza shops. Khayelitsha was thus selected as it is one of the largest townships in Cape Town with a large number and variety of informal, survivalist enterprises, who are operating in an unusually competitive environment. With the help of snowballing, one of the nonprobability sampling techniques, 150 subjects were selected. According to Fox and Bayat (2007:59), in this sampling technique the researcher approaches one subject of the study who in turn refers the researcher/s to another suitable member/s to be studied. Therefore this sampling method is suitable, especially considering the enormous size of Khayelitsha and the need to capture a willing and representative sample.

Research instruments, procedure and data analysis: A standardized questionnaire containing closedended (Likert scaled) and open-ended questions was designed. The questionnaire items were scrutinized by an ethics committee of a faculty of business in an institution of higher learning in South Africa. Following a pre-assessment of the study area (Khayelitsha), the researchers considered it necessary to appoint interpreters who are fluent in isiXhosa (the dominant language of the subjects). This approach was helpful as it facilitated faster data collection. We also obtained data by conducting informal (unstructured) interviews with some of the participants. The interview questions were primarily devoted to gaining insight into the participants' perception of the significance of education and training in their retail businesses. In line with research ethics, subjects were informed of their rights: they were at liberty to discontinue with the process; they did not have to disclose their identities; and they were at liberty not to respond to any questionnaire item that they were uncomfortable with. As far as we were concerned, we viewed the appointment of interpreters as helpful as we did not have the 'space' to influence the subjects' responses. 128 usable questionnaires were returned. For analysis, use was made of SPSS (version 23) for the quantitative data, which assisted in the descriptive presentation of results. Information obtained through the informal interviews was used to draw inferences and to support our interpretation, findings and conclusions.

\section{Results and discussion}

This section is dedicated to displaying and discussing the results of the study.

Informal survivalist retail entrepreneurs: Table 1 explicitly shows a variety of businesses owned by the subjects.

Table 1: Variety of informal survivalist retail entrepreneurs

\begin{tabular}{lllll}
\hline Business category & Frequency & Percent & Valid Percent & Cumulative Percent \\
\hline Braai-meat & 5 & 3.9 & 3.9 & 3.9 \\
Dress-making & 10 & 7.8 & 7.8 & 11.7 \\
Timber \& used-building & 5 & 3.9 & 3.9 & 15.6 \\
material & 1 & .8 & .8 & 16.4 \\
Car-trailer producer & 5 & 3.9 & 3.9 & 20.3 \\
Clothing stall & 3 & 2.3 & 2.3 & 22.7 \\
Fishery & 7 & 5.5 & 5.5 & 28.1 \\
Fruit \& Vegetables stall & & 3.1 & 3.1 & 31.3 \\
Furniture upholstery \& bed & 4 & .8 & .8 & 32.0 \\
makers & 1 & 22.7 & 22.7 & 54.7 \\
Posters \& mirrors & 29 & 25.8 & 25.8 & 80.5 \\
Kasi restaurant & 33 & 19.5 & 19.5 & 100.0 \\
Shebeen & 25 & 100.0 & 100.0 & \\
Spaza shop & 128 & & & \\
Total & & & & \\
\hline
\end{tabular}

The Kasi restaurants supply more of South African traditional food with a mix of Western food and soft drinks. The term Kasi generally means township, and is popularly used in such communities, especially by young people. Therefore, to emphasise the difference between township and up-market restaurants such as 
MacDonald, KFC, and Spur, the term Kasi restaurant was necessary. We categorise them within the retail industry as most of them operate in the form of a take-away eatery due to a lack of space in the business premises. In fact, most of these eateries are operated from shipping containers.

It was observed that there are still some locally-owned spaza shops (especially in the informal-settlements) regardless of the tough competition posed by other rivalries, including the foreign nationals who are known for dominance in the category of informal spaza shop businesses. Shebeens are also among popular businesses in the informal settlements. It is illegal to sell alcohol without a liquor license in South Africa, yet there are many operating without licences in the townships. Perhaps the reason for this is that it is not easy for the Police to access such areas due to the clutter of shacks and the inaccessible vehicular access. The level of alcohol consumption is high in the townships, and therefore it can be argued that shebeens are viable businesses in the townships.

\section{Figure 1: A Kasi restaurant in Khayelitsha}

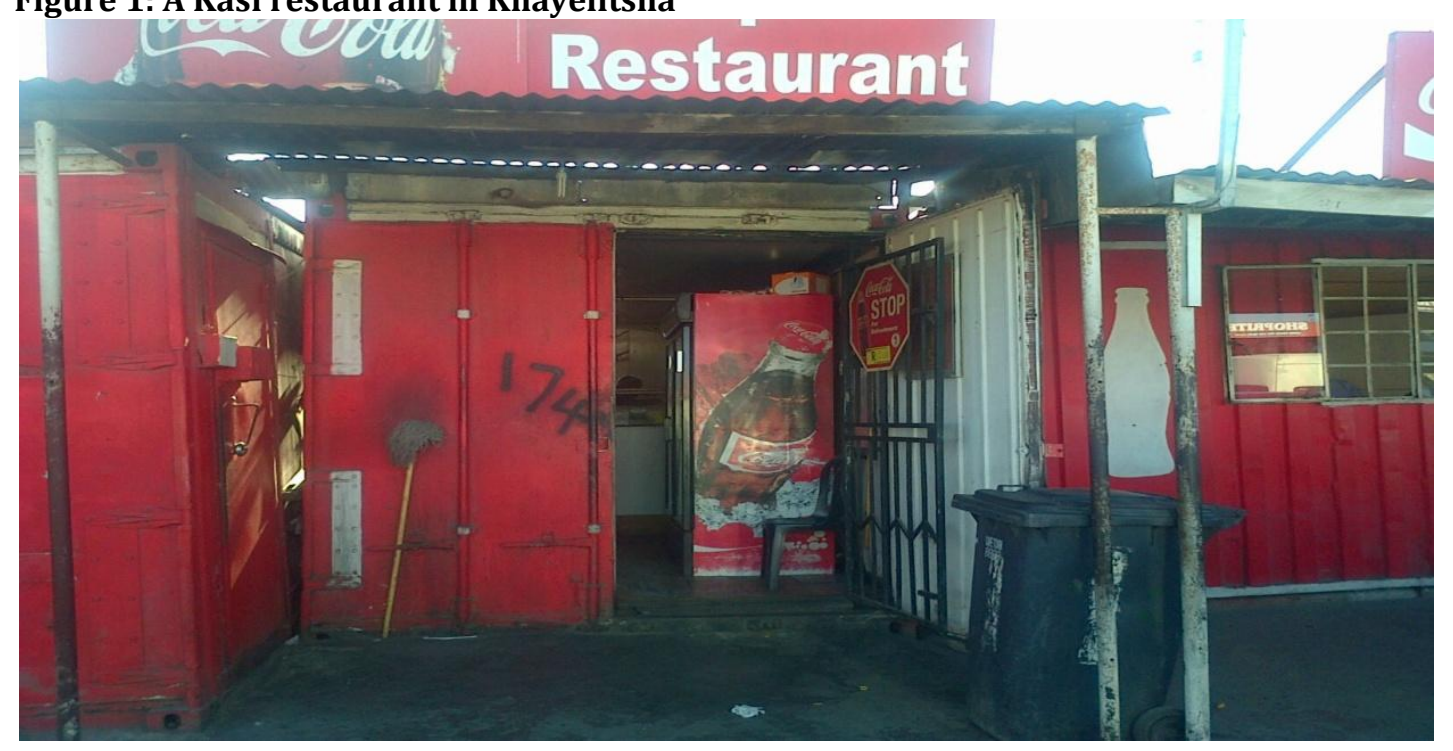

Level of education achieved: The results in Table 2 are crucial in the study, as they show levels of schooling among the subjects in a cross tabulation.

Table 2: Level of education acquired

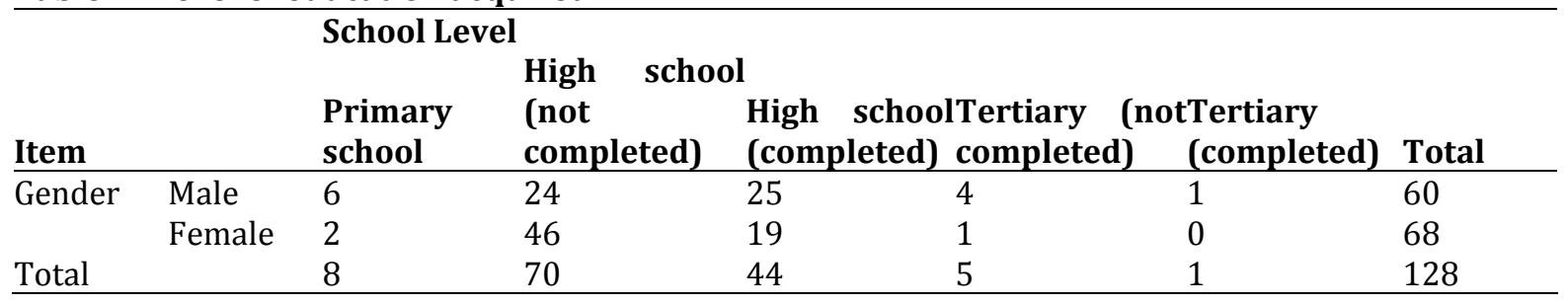

What can be drawn from these findings is that the levels of schooling among the subjects are very low, especially among females. This relates to what the literature maintains regarding survivalist retail entrepreneurs' low levels of formal education (Nieman \& Nieuweuhuizen, 2009:41). Herrington, Kew and Kew (2009:12) point out that inadequate skills and education are the key impediments to the development of entrepreneurship in South Africa. Gordhan (2012:21) also highlights that the unpredictable and competitive global environment forces many governments across the world to prioritise investment in their education. Arko-Achemfuor (2014) asserts that the types of education offered by many institutions of lower and higher learning largely focus on the theoretical angle rather than the practical side, which limits a learner's ability to apply the lessons learned. Hence, in this study we propose a broader investment in informal education (because it specialises in practical training) for the survivalist retail entrepreneur. Equipping survivalist retail 
entrepreneurs with more customised and lucrative skills for business will not only nurture their businesses, but will also attract more entrants to entrepreneurial businesses. Through observation one is able to acquire large, integrated units of behaviour without having to build up the behavioural patterns regularly by tedious trial and error (Bandura, 1971:2). This means that an individual who learns by observation has a greater chance of success when applying whatever behaviour s/he has learnt from others.

Creativity to improve business products/services: In the context of business, creativity is all about the capability to generate a wide range of different ideas (Booysen, 2015:46). One however cannot escape the fact that ideas need to be correctly implemented at the right time. Table 3 indicates the frequency with which respondents felt that they used creative ideas to improve their businesses.

Table 3: Creativity to improve business products/services

\begin{tabular}{cllll}
\hline Response category & Frequency & Percent & Valid Percent & Cumulative Percent \\
\hline Always & 10 & 7.8 & 7.8 & 7.8 \\
Often & 52 & 40.6 & 40.6 & 48.4 \\
Occasionally & 28 & 21.9 & 21.9 & 70.3 \\
Rarely & 16 & 12.5 & 12.5 & 82.8 \\
Never & 22 & 17.2 & 17.2 & 100.0 \\
Total & 128 & 100.0 & 100.0 & \\
\hline
\end{tabular}

Looking at the results in Table 3, one will notice that most of the subjects admit that creative ideas to improve their business concept are not in place (for instance $52.6 \%$ of respondents said they used creative ideas 'occasionally', 'rarely' or 'never', with only $7.8 \%$ saying 'always'). Research shows that creativity and innovation are some of the key personal traits of an entrepreneur. Creative behaviour and thinking may result in better performance and innovative outputs (Nieman \& Nieuweuhuizen, 2009:55). We also argue that skills training are key to creative and innovative behaviour. Nieman (2006:11) further connects innovative behaviour to access to technological systems, which suggests that through more customised training a survivalist retail entrepreneur individual can advance his business through creativity.

Rivalries: McDaniel and Terblanche (2004) categorise competitive advantage in a business venture as the 'quality of service, customer value, customer satisfaction, customer-orientated personnel, well-trained employees, employee empowerment, and teamwork'. Without this, the ability to handle competitive rivalry is limited. Table 4 provides the respondents opinions with regard to the level of competitiveness in their markets.

Table 4: Competition to the business

\begin{tabular}{cllll}
\hline Response category & Frequency & Percent & Valid Percent & Cumulative Percent \\
\hline Always & 91 & 71.1 & 71.1 & 71.1 \\
Often & 9 & 7.0 & 7.0 & 78.1 \\
Occasionally & 9 & 7.0 & 7.0 & 85.2 \\
Rarely & 14 & 10.9 & 10.9 & 96.1 \\
Never & 5 & 3.9 & 3.9 & 100.0 \\
Total & 128 & 100.0 & 100.0 & \\
\hline
\end{tabular}

An overwhelming majority of $71 \%$ admit that competition is always high in the marketplace. This implies that the business environment is very competitive; as a result businesses can emulate competitors' product/service offering, whereas customer's buying decisions are based on rational reasons. Customers avoid other businesses selling similar products/services to buy from a business of choice because of competitive advantage (McDaniel \& Terblanche, 2004). Therefore, for as long as these enterprises continue to operate without this special ingredient, competition will remain a challenge. Survivalist retail entrepreneurs seem to lack fundamental business skills, and rather rely more on what works for them. Burke (2006:96) insists that networking is another useful tool, if one meets helpful contacts, who can give advice, information and resources that can facilitate his/her business venture. Facing competitive rivalry, networking skills are 
vital. Evidence of the use of the right networks, can be traced to the success of foreign nationals who successfully operate spaza shops in South African townships (Liedeman et al., 2013:4).

\section{Conclusion and Recommendation}

Two very important findings have emerged from this study. The first relates to an admission by the majority of the subjects that their businesses are not doing particularly well owing to their lack of basic business skills. The second relates to the subjects' admission that the competitive practices of the immigrant retail entrepreneurs can be successfully competed against if they had adequate business sense, knowledge and abilities. Evidence is found in the statements by some of the subjects. For instance, one of the subjects said 'I have no doubt in my mind that if I went for simple business lessons, I am able to submit applications for funding and confidently defend the submission when I am called upon to do so'. Another subject indicated a willingness 'to participate in any form of training that will help me grow my business'. However, what was quite interesting to the researchers was the concern shown by the owners of a local eatery in Khayelitsha. These subjects questioned the significance of teaching style '....as though they were in university'. The subjects disclosed that they attended some training programs organised by a certain agency where they were subjected to 'too much talk (theory)'. When pressed further to share their overall assessment/perception of the training they attended, they said that they were lost and could not connect with the trainers. We infer from this statement that the facilitators of the programme may not have engaged the subjects practically. With regard to competitive muscle, we infer that if the subjects understood competitive practices, they are better able to come up with creative ways of keeping their businesses going instead of playing second fiddle to immigrant retail entrepreneurs in the townships. In fact, recent entrepreneurship literature suggests the need for cooperation and/or collaboration with identified competitors. Xesha, Iwu and Slabbert (2014) are of the opinion that collaborative relationships enable the growth of businesses, as participants share information as well as other resources. In the case of Khayelitsha, immigrant retail entrepreneurs should not be viewed as monsters but as partners who can be beneficial to the growth of businesses in the township. We suggest that instead of antagonizing immigrant retail entrepreneurs, local business owners should embrace them, learn from them and possibly become partners in their wholesale/bulk buying practices.

In light of the key findings of the study and the above interpretations, we are of the view that the survivalist retail entrepreneur is able to transit to a much bigger enterprise if he is exposed to skills programmes that focus on providing practical training in entrepreneurship. The package should include hands-on lessons on business management incorporating simple bookkeeping practices, proposal writing and presentation, and so on. The facilitation should take place in a simulated business environment with experienced and highly skilled staff to develop learning material and conduct such training. Sustainability of such programmes is only possible if credible partnerships with critical funding and support agencies are in place; if a range of assessment tools that align with the objectives of a programme as well as the participants' abilities are available. We insist that such training should take a hands-on approach because of the value we find in Brush, Neck and Greene (2015), Maritz and Donovan (2015), and Karia, Bathula and Abbott (2015) who have consistently argued for practice based learning owing to its potential to excite learners and reduce the risk of learners not turning up for lessons.

Should survivalist retail entrepreneurs in Khayelitsha be expected to add value to the economy by creating employment opportunities, it is essential that they are provided with skills training on a regular basis by government agencies and other stakeholders such as the W\&R SETA. It is, judging by the participants' responses, possible that their businesses will blossom, thus requiring extra capacity in the form of employees. Interestingly, although Eresia-Eke and Rath (2014) found no statistically significant relationship between business owners' financial literacy and enterprise growth, an estimated $33 \%$ who were financially literate revealed that they increased their number of full time employees. While we do not consider this number large enough, we are equally adamant that investment in business literacy of a business owner is a worthwhile investment. In fact, in Jordan, Magableh, Kharabsheh, and Al-Zubi (2011) found improved performance in SMME profit, revenue and employment as a result of training. Elsewhere, Malaysia, Yahya, Othman, and Shamsuri (2012) found a 'significant and positive relationship between training and SMEs' performance.' We conclude that survivalist retail entrepreneurs in Khayelitsha can create jobs if they have the right opportunity (i.e. skills development) to grow their businesses. 
Scope for future research: This paper only focused on the informal survivalist retail entrepreneurs, in a large township in the Western Cape Province of South Africa. South Africa has nine Provinces. This alone underscores the necessity for further relevant studies around the subject of informal survivalist retail entrepreneurship and its development in other geographical settings of the country.

\section{References}

Arko-Achemfuor, A. (2014). Teaching youth and adults through education with production: the case study of Tiger Kloof Educational Institution. Mediterranean Journal of Social Sciences, 5(1), 607-612.

Bandura, A. (1971). Social learning theory. New York: Library of Congress.

Bear, M., Bradnum, P., Tladi, S. \& Pedro, D. (2005). Making retail markets work for the poor - why and how Triple Trust Organisation decided to intervene in the spaza market in South Africa. Washington, D.C.: The SEEP Network.

Bhorat, H. (2001). Fighting poverty: labour markets and inequality in South Africa. Cape Town: Juta.

Booysen, K. (2015). Dynamics of entrepreneurship. Cape Town: Juta.

Brush, C., Neck, H. \& Greene, P. (2015). A practice-based approach to entrepreneurship education. Evolving entrepreneurial education: innovation in the Babson Classroom, 35.

Burke, R. (2006). Entrepreneurs Toolkit. Cape Town: Burke Publishing.

Charman, A. Petersen, L. \& Piper, L. (2012). From local survivalism to foreign entrepreneurship: the transformation of the spaza sector in Delft, Cape Town. Transformation: Critical Perspectives on Southern Africa, 78(1), 47-73.

Choto, P., Tengeh, R. K. \& Iwu, C. G. (2014). Daring to survive or to grow? The growth aspirations and challenges of survivalist entrepreneurs in South Africa. Environmental Economics, 5(4), 93-101.

Co, M. J., Groenewald, M. J., Mitchell, B., Nayager, T., van Zyl, J., Visser, K., Train, W. \& Emanual, B (2006). Entrepreneurship: fresh perspective. Cape Town: Pearson.

Daniel, N. \& Sifuna, D. N. (2007). The challenge of increasing access and improving quality: Analysis of universal primary education interventions in Kenya and Tanzania since 1970s. International Review of Education, 53, 687-699.

Eresia-Eke, C. E. \& Raath, C. (2013). SMME owners' financial literacy and business growth. Mediterranean Journal of Social Sciences, 4(13), 397.

Fal, M. Daniels, R. Williams, A. \& Bantobetse, R. (2011). The state of entrepreneurship in South Africa: the key archetypes of an entrepreneurial culture. Bryanston: Endeavor South Africa.

Fox, W. \& Bayat, M. S. (2007). A guide to managing research. Cape Town: Juta.

Gordhan, P. (2012). 2012 Budget Speech. Pretoria: Communications Unit National Treasury.

Gyan, C., Mabefam, M. G. \& Michael-Baffoe, M. (2014). Push out or drop out? Taking a critical look at the poor performance and drop-out of students of the JSS/JHS Programme in Ghana. Academic Journal of Interdisciplinary Studies, 3(1), 409-420.

Herrington, M., Kew, J. \& Kew, P. (2009). Tracking entrepreneurship in South Africa: a GEM perspective [online]. Available at: http://www.gsb.uct.ac.za/files/Gembook2009.pdf. [10 June 2011].

Hutchinson, M. V. \& de Beer, M. (2013). An exploration of factors that limit the long-term survival and development of micro and survivalist enterprises: empirical evidence from the informal economy in South Africa. Mediterranean Journal of Social Sciences, 4(13), 237-245.

Karia, M., Bathula, H. \& Abbott, M. (2015). An experiential learning approach to teaching business planning: connecting students to the real world. In Exploring Learning \& Teaching in Higher Education. Swinburne University of Technology: Springer-Veriag Berlin.

Levinsohn J. (2008). Two policies to alleviate unemployment in South Africa. Centre for International Development at Harvard University (CID) Working Paper, 166.

Liedeman, R., Charman, A. Piper, L. \& Petersen, L. (2013). Why are foreign-run spaza shops more successful? The rapidly changing spaza sector in South Africa [online] Available at: www.econ3x3.org./article/why-are-foreign-run-spaza-shops-more-successful-rapidly-changingspaza-sector-south-africa. [02 May 2015].

Mago, S. \& Toro, B. (2013). South African government's support to small, medium micro-enterprise (SMMEs): the case of King William's town area. Journal of Economics, 4(1), 19-28.

McDaniel, L. H. \& Terblanche, B. (2004). Marketing: SA edition. Cape Town: Oxford University Press. 
Magableh, I. K., Kharabsheh, R. \& Al-Zubi, K. A. (2011). Determinants and impact of training: the case of SMEs in Jordan. International Journal of Economics and Finance, 3(5), 104-116.

Maritz, A. \& Donovan, J. (2015). Entrepreneurship and Innovation: Setting an agenda for greater discipline contextualisation. Education+ Training, 57(1), 74-87.

Modisaotsile, B. R. (2012). The failing standard of basic education in South Africa. Africa Institute of South Africa. Policy brief No. 72. March [online]. Available at: http://www.ai.org.za/wpcontent/uploads/downloads/2012/03/No.-72.The-Failing-standard-of-basic-education-in-Southafrica1.pdf. [20 June 2014].

Naidoo, R. \& Urban, B. (2010). The relevance of Operational Skills towards Business sustainability: A focus on SMME manufacturers in the Vaal Triangle region. Acta Commercii, 4, 234-248.

Nieman, G. (2006). Small business management. A South African approach. Pretoria: Van Schaik.

Nieman, G. \& Nieuwenhuizen, C. (2009). Entrepreneurship. A South African perspective. Cape Town: Interpak Books.

Rolfe, R., Woodward, D., Ligthelm, A. \& Guimaraes, P. (2010). The viability of informal micro-enterprise in South Africa. Presented at the Conference on-Entrepreneurship in Africa, Whitman School of Management, Syracuse University, Syracuse, New York, April 1-3, 2010.

South Africa. (2003). National Small Business Amended Act No. 26, 2003. Government Gazette, 461(25763), 110, November 26.

Turton, N. \& Herrington, M. (2012). Global Entrepreneurship Monitor, South Africa. Cape Town: The UCT Centre for Innovation and Entrepreneurship.

Xesha, D., Iwu, C. G. \& Slabbert, A. (2014). Business relationships as a driver of success for small, medium, and micro enterprises (SMMEs) in South Africa. Journal of Economics, 5(1), 37-43.

Yahya, A. Z., Othman, M. S. \& Shamsuri, A. L. S. (2012). The impact of training on small and medium enterprises (SMEs) performance. Journal of Professional Management, 2(1), 15-25. 